\title{
Analysis of Strategic Planning Process at Rosa De Lima High School Tondano City, Minahasa Residence, Indonesia
}

\author{
Frily Pricila Piri Harold Lumapow Jeffry S.J Lengkong \\ Magister Education Management Postgraduate Program \\ Manado State University, Indonesia
}

\begin{abstract}
Absract
This research aimed at finding complete description on: 1) strategic planning process at Santa Rosa De Lima Tondano Catholic High School in Minahasa Residence. 2) obstructing factor of the strategic planning process at Santa Rosa De Lima Tondano Catholic High School in Minahasa Residence. 3) supporting factor of the strategic planning process at Santa Rosa De Lima Tondano Catholic High School in Minahasa Residence. 4) efforts to contend the strategic planning process at Santa Rosa De Lima Tondano Catholic High School in Minahasa Residence. Qualitative research method was used in this research. The techniques of data collection were: 1) observation, 2) interview, 3) documentation study. Data analysis process was conducted according to the preliminary process of data collection circle and in the course of data collection process. Reverification was done due to some odd data, then grounded final conclusion was drawn. Criteria of data validity checking as follows: 1) credibility, 2) transferability, 3) dependability and 4) conformity. Based on the findings and data analysis, the research conclusions were: 1) The strategic planning process at the Santa Rosa de Lima Tondano Catholic High School in general has gone well, but there are still inequalities because there are things that have not been prepared in advance and there are stages that are not fully implemented. 2) Obstructing factor of the strategic planning process at Santa Rosa De Lima Tondano Catholic High School are: Less involvement of stakeholders; The strategic plan formed is not disseminated to stakeholders; The time of preparation of the Strategic Plan is quite long because a lot is taken up by the busyness of each team member; There is no budget for this activity. 3) Supporting factor of the strategic planning process at Santa Rosa De Lima Tondano Catholic High School are: Expertise and skills of the drafting team members; The accuracy of the program to be implemented with school needs; Self-giving totality of all team members; There are donors who cover costs. 4) Efforts to contend the strategic planning process at Santa Rosa De Lima Tondano Catholic High School are that the school begins to socialize the school strategic plan by distributing copies of documents to stakeholders. That way they are interested in finding out how to compile the strategic plan and they begin to understand the existing strategic plans. From this, they naturally began to train themselves to analyze school conditions. And this will be followed by training by experts, who are currently championed by the current headmaster. To involve stakeholders, time and budget planning in the strategic planning process, will be sought when there are improvements to the school's strategic plan.
\end{abstract}

Keywords: Strategic Planning Process, Santa Rosa De Lima Tondano Catholic High School

DOI: $10.7176 / \mathrm{JEP} / 10-17-03$

Publication date: June $30^{\text {th }} 2019$

\section{Introduction}

Planning is always needed in everything we will do. Especially if it is related to business and organization. It is very unlikely if a company or organization does something without prior planning. Without planning, something that is done will definitely not be structured and can fall apart because of no preparation. With the planning, a list of needs and concepts related to the activities to be carried out can be specified. Careful planning is the key to the success of an activity. Planning is one of the functions in the management process used in managing current conditions to be carried out in the future or in the future. Planning is the first and foremost function in management. This statement is in line with Terry's opinion (in Widjaya, 1995) which states four basic functions of management, namely planning, organizing, actuating, and controling (POAC). Gulich (in Widjaya, 1995) also suggests seven types of management functions, namely planning, organizing, staffing, directing, co-ordinating, reporting, budgeting abbreviated as POSDCORB, where planning is also the first function.

Enoch (in Kambey, 2016: 127) argues that planning is a process of preparing things that will be done in the future, to achieve a predetermined goal. Hayashi (in Kambey, 2016: 127) also emphasizes that planning is a gradual process of organized action to bridge the differences between existing conditions and organizational aspirations. Furthermore, Newman (in Kambey, 2016: 128) suggests that planning is determining what will be done. Planning contains a broad set of decisions and explanations of objectives, policy decisions, programs, methods, procedures and activities to be carried out.

Barnawi and Arifin (in Farhurohman, 2017: 78) explain that strategic planning is a result-oriented process that wants to be achieved in a certain period of time by taking into account potential, opportunities and constraints that might arise. Then Salusu (in Rojak, 2017: 24) states that strategic planning is a process of 
determining what an organization wants in the future and how to achieve it or a process that explains goals. Further more according to Lidinillah (2013: 4) "strategic planning is a fundamental decision that will direct the organization to strategic achievements according to the organization's vision in the future".

The results of the strategic planning process are documents called strategic plans. The strategic plan is a road map to direct an organization from its present condition to its condition in the next five or ten years (Shouthern University at New Orleans, in Lidinillah 2013: 4). Barnawi and Arifin (in Farhurohman, 2017: 78) also emphasize that strategic plans are planning documents that are used as guidelines for achieving organizational goals within a certain period of time. So the strategic plan is school policies that are arranged in a systematic and detailed way to be used as a guide in achieving goals.

The strategic plan function is made besides an administrative obligation that must be provided by an educational institution, but also must be used as a guideline to achieve the goals of an educational organization. Because in the current era, the community has many choices to enter the desired school because there are so many schools appearing with various visions such as vocational schools, religion-based schools, academic based, and others. On the other hand, the presence of many schools of course raises the existence of competition between schools in seizing customers who in this case are students. Schools must have an accurate strategy to develop school programs so that they become excellent schools and choices for the community. For this reason, the school's strategic plan must be used as it should, because in the strategic plan the school policies have been described as a strategy to deal with existing competition.

Based on the results of preliminary observations at the Santa Rosa De Lima Tondano Catholic High School in June 2018, data were found: 1) the location of this school is in a strategic environment because it is located in a place that can be accessed by public vehicles, 2) the condition of the school environment is well organized starting from the park, there are shady trees, 2-storey school buildings and equipped with statues that characterize Catholic schools 3) in one school complex also stands Santa Rosa de Lima Tondano Catholic Middle School 3) Students come from various regions even from Central Sulawesi area 4) male and female dormitories are also provided 5) My Future Day program (HDS) is available for students who live in dormitories, who work together with Dutch students under the leadership of Mr. Gerald and Mr. Ritsko 6) cooperation with several universities in North Sulawesi and this school is a target school of the Catholic University of De La Salle Manado. However, from these advantages this school still loses competitiveness with other schools in several respects, namely 1) there is still a lack of students even though this school is the only Catholic private high school among 30 high schools in Minahasa Regency which when compared to the number of Catholics in Minahasa district is $16 \%$ or equal to 53,245 people (based on North Sulawesi BPS figures for 2015), 2) lacking discipline, 3) quality of learning that is still low due to inadequate infrastructure, 4) lack of academic achievement .

By looking at the school administration especially the local School Strategic Plan which is the period of 2016-2020, this school should be able to excel and become an effective high school, because in the existing Strategic Plan the things that have become high school goals and targets have been reflected. Catholic Santa Rosa De Lima Tondano about the future of the school. Thus, the question arises about how the strategic planning process in this educational institution. Because this could be an inequality that affects the development of the quality of education in this school. Because the logic is, if a plan has been arranged well, surely the implementation will be controlled properly because it only follows the existing planning flow. If the planning has reflected a convincing work program, why have the achievements of existing programs not been realized properly.

In this condition, the researcher suspects that the ability to process the local school strategic planning has not been maximized due to several reasons, namely in the preparation of the local Principal's strategic plan not involving stakeholders, self-evaluation or self-awareness of all school members to encourage existing school programs low, lack of socialization to all school members and the surrounding community about work programs that are to be implemented, and lack of evaluation on their implementation because the purpose of the evaluation of this activity is to be input material for establishing a better strategic plan. For this reason, a new breakthrough is needed in an effort to develop the strategic planning capabilities of these educational institutions in order to excel in various aspects.

The aim of the study was to analyze and describe the strategic planning process at the Santa Rosa De Lima Tondano Catholic High School. Whereas specifically this study aims to find out: (1) The process of strategic planning at Santa Rosa De Lima Tondano Catholic High School in Minahasa District. (2). Obstacles in the strategic planning process at the Santa Rosa De Lima Tondano Catholic High School in Minahasa District. (3) Supporting factors in the strategic planning process at Santa Rosa De Lima Tondano Catholic High School in Minahasa District. (4) Efforts can be made to overcome obstacles in the strategic planning process at the Santa Rosa De Lima Tondano Catholic High School in Minahasa District, Indonesia 


\section{Literature Review}

\subsection{Education Planning}

The national education department (in Engkoswarah \& Komariah, 2010: 132) defines education planning as a process of drawing up a picture of future educational activities in order to achieve predetermined changes / educational goals. In the definition stated that planning is intended to change the future. The future of the desired education is quality education that is dealt with in a structured and programmed manner through planning from the start so that the future is not the result of mere coincidence. According to Coombs (in Engkoswarah \& Komariah, 2010: 132) educational planning is a rational activity of systematic analysis of the process of development of education with the aim that education is more effective and efficient. The Waterston (in Engkoswarah \& Komariah, 2010: 132) states that "education planning is a form of educational investment that can be carried out and development activities that are based on economic considerations and social costs and benefits".

As an educational organization, each school must develop a Strategic Plan which is also known as the School Work Plan. This is supported by the existence of policies, namely RI Minister of National Education Regulation No. 19 of 2007 concerning Education Management Standards by Primary and Secondary Education Units, Article 1 paragraph $1 \& 2$ reads "(1) Every education unit must meet the education management standards that apply nationally, (2) Standards for education management as referred to in paragraph 1 are listed in the Appendix of the Ministerial Regulation. In the appendix the Strategic Plan is contained in the first part of the appendix about Program Planning, namely the School Work Plan (RKS).

Republic of Indonesia Minister of Education and Culture No. 22 of 2015 concerning the Ministry of Education and Culture's Strategic Plan for 2015-2019 Article 1 paragraph 2 which reads "The strategic plan is used as a guideline for each development organizer and development of education and culture both at the central and regional levels", and Article 2 paragraphs $1 \& 2$ reads "Implementation of plans Strategies are evaluated annually as a whole at the end of the implementation of the strategic plan. This gives the meaning that every educational organization, especially schools, must have a strategic plan as the first step in the process and action to be qualified in accordance with the expectations of all school people and the surrounding environment. Thus education planning is the process of determining decisions relating to the objectives to be achieved, the resources to be empowered, and the techniques / methods that are chosen appropriately to carry out actions for a certain period of time so that the implementation of the education system can be carried out effectively, efficiently, and quality.

The future cannot be described clearly, but we need to estimate the possibilities that will occur in the future by reading the trends in the present. Planning that is well formulated by considering what has been achieved, reading what is happening and projecting trends that occur in the future allows the planning to be a change tool that has a high level of certainty with minimal risk. The national education department (in Engkoswarah \& Komariah, 2010: 133) explains that education planning in the scope of the school aims to 1) ensure that predetermined educational changes / objectives can be achieved with a high level of certainty and small risk. 2) support coordination betweenactors school. 3) guarantee the creation of integration, synchronization and synergy between school actors, between schools and district / city education offices, and between times ensuring the linkages and consistency between planning, budgeting, implementing, and monitoring 4) optimizing the participation of school and community members, and 5 ) guarantee the achievement of efficient, effective, equitable and sustainable use of resources.Good planning is done to achieve: 1) protective benefits, namely to keep the goals, sources and techniques / methods of high relevance with future demands so as to reduce decision risk 2) positive benefits, namely productivity can increase in line with the formulation of a comprehensive plan and right.

\subsection{Education Planning Approach}

Engkoswarah \& Komariah (2010: 133-134), explained that based on the size of the organization, education planning has scope of micro (school), meso (district / city / province), and macro (national) sizes for each type, level, and unit education. In its formulation, education planning can use several approaches, namely: 1 . Workforce planning approach; directed to create graduates who have the skills needed by the workforce and the times. An example is the life skills program at school and Broad Based Education. 2.Approach to social demand; education planning accommodates the aspirations and demands that develop in society in various dimensions of life such as moral, social, economic, and others. An example is inclusion education, 9 years is reasonable. 3.Good value education; education is social oriented but in practice still considers the value of efficiency in terms of reducing waste and increasing added value. This approach means that the results of education have high productivity and quality by creating programs that are relevant to the demands of the community and used in the times. Examples are PSG (Dual Education System), and the SBM program. 4.System approach; Educational planning is focused on organizations as systems that have interrelated components. The system approach is the derivation of the term system analysis by applying system thinking in looking at an object we are facing. 
Planning the education system does not only focus on improving educational inputs or processes, and outputs partially but all components and systematic systems must be studied and targeted. Examples are effective school planning, quality improvement programs at every type and level of education.

\subsection{Principles of Educational Planning}

The national education department (in Engkoswarah \& Komariah, 2010: 134) details the educational planning principles, namely:

1) Improve education outcomes

2) Bring better change (improvement / development)

3) Demand driven

4) Comprehensive

5) Linkages with (RPS, Provincial Office Education Plan, Renstrada, Repetada, etc.)

6) Participation

7) Representation

8) Data driven

9) Realistic in accordance with the results of the SWOT analysis

10) Basing on the results of reviews and evaluations

11) Integrity

12) Holistic / systemic

13) Transparency

14) Linkages and compatibility with the plans of the relevant agencies.

While Banghart and Trull (in Engkoswara \& Komariah, 2010: 134-135) reveal dimensions as the principle of educational planning as follows:

1) Significance; the degree of significance is influenced by the social interests that exist in the purpose of education. To achieve this goal, the planner must determine the guideline and evaluation criteria for the decisions that have been made and have set goals.

2) Feasibility; the plan made must be guided and based on the appropriate analysis situation and procedure. Many factors can influence the existence of planning, where all possibilities can occur and affect the planning that has been set. Political circumstances, feasibility of techniques, estimation of costs, and several other aspects are aspects that require realistic consideration.

3) Relevance; increased use of technology and sophisticated planning techniques have broadened the concept of relevance. Planning places the main pressure on the process in accordance with the achievement of goals. The concept of relevance is very important in implementing an education plan. Things that must be solved include organizational realism, the degree of relevance related to the process, the assurance that the plan will be more specialized in solving problems in line with the time and scope of planning.

4) Certainty; the right calculation must be identified by taking into account all irregularities to be considered.

5) Savings; this principle states that plans must be designed in a simple framework and increase sensitivity to identify interactions between components.

6) Adaptability; the education plan should be dynamic. A complete plan, deviation in planning as far as possible is reduced to the stated objectives can be achieved through a varied process.

7) Time; an important factor, consider the natural cycle in the aspects planned.

8) Monitoring; includes the determination of educational criteria to see whether planned planned efficiently or not.

9) Subject matter; what substance is being planned is developed by McClure such as: goals and objectives, programs and services, human resources, physical, financial, government, and social resources.

Types and Scope of Educational Planning

The type of planning according to Satori (in Engkoswarah \& Komariah, 2010: 135-136) consists of:

1) Planning starts at the top down planning level

2) Planning starts at the bottom-up down planning level

3) Planning diagonals

4) Rolling plan

5) Combined top-down and bottom-up planning

6) Strategic planning

7) Operational planning

Strategic Planning.

Strategic planning consists of the words planning (planning) and strategic (strategic). The following are some notions of strategic planning, namely: Texas Workforce Commission (in Lidinillah, 2013: 3) "Planning sets direction for something. Usually, we start with the desired results and work backwards to identify what will produce these results, Strategic is a method for achieving goals and objectives, and Strategic Planning enables 
organizations to make fundamental decisions that guide them to the vision of developing the future". Lubis (2008) "Strategic Planning is the process of organization placement so that future prospects can be enlarged and the risks to be achieved can be minimized. In other words, strategic planning is to make choices that relate to positions that allow the organization to be placed, and conduct an evaluation of those choices so that the most desirable activities will be identified. Strategic planning is a process carried out by formulating strategic planning and policies that determine changes in the character or direction of the organization ".

Syahrul (in Lubis 2008: 47) "Strategic Planning is the process by which organizational guiding members formulate the organization's future vision and develop the procedures and operations needed to achieve it".Uganda Network of AIDS Service Organizations (in Lidinillah, 2013: 4) "Strategic planning is the process of determining: (1) what your organization wants to achieve; (2) how you will direct the organization and resources to achieve this goal for several months and years "Shouthern University at New Orleans (in Lidinillah, 2013: 4) "A strategic plan is a road map to direct an organization from its current condition to a condition of five or ten years". California State Department of Finance (in Lidinillah, 2013: 4) "Strategic planning is defined as a longterm term, a future-oriented assessment process, goal setting, and strategy building that maps the explicit path between present and future visions, which depend on careful consideration of organizational and environmental capabilities, and cause priority-based resource allocation and other decisions ".Bryson \& Alston (in Lidinillah, 2013: 4) "Strategic planning is a strong effort to produce fundamental decisions and actions that shape and guide what an organization (or other entity), what it does, and why it does".

Norman (in Lubis, 2008: 48) "Strategic planning is an activity to determine the company's long-term development plan in a certain way, based on all available facts, in relation to the company's final goals and the ways that will be taken to achieve them. This time scale for planning is between 3 and 10 years (even more for certain industries). The most basic demand for the preparation of a company plan is the need to determine precisely the line of business that will be occupied. The second requirement is that such a plan must be flexible, meaning that it is subject to the most recent events to change each criterion based on it. "Kerzner (in Lubis, 2008: 48) "Strategic planning is a management tool used to manage current conditions to project future conditions, so that strategic plans are a guide that organizations can use from the current conditions for them to work towards 5 for the next 10 years ".

Lidinillah (2013: 4) "Strategic planning is a fundamental decision that will direct the organization to strategic achievements in accordance with the vision of organization in the future. Strategic planning relates to what the vision, mission, goals, objectives and achievements of the organization in the future and relates to how the organization can mobilize existing resources to achieve these goals ". Lubis (2008: 48) "Strategic planning is the process of deciding on a program that an organization will do, by identifying what should be and what can be done. A guide for the organization from the conditions being faced to the conditions of the next few years (future) in order to achieve maximum and appropriate goals.

Strategic planning is formulated to answer current organizational problems and a long future. So that includes a set of activities and specific results that will be carried out and achieved. More important is how to implement the formulation of strategic planning in real activities. Actions that will be given for problem solving, as well as the expected results must guarantee to be applied. A strategic plan must describe the high ideals of the organization but must remain realistic. Actions, results and implementation are the nature of the formulation of a strategic plan (Syahrul, 2017: 4). As planning on a large scale, strategic planning takes into account the involvement of all organizational stakeholders. Internal and external stakeholders must be given certain spaces to be involved in contributing to a strategic plan. In past planning practices, it was very common to find low levels of community participation and members of the organization itself in the planning process. Usually, work making strategic planning is only a practice that is attached to top management (top manager) or middle manager level (middle manager). Of course the participation of members of organizations and communities is limited to their knowledge, skills and understanding of the problem. Like wise the involvement of community members through certain figures needs to be emphasized on expertise, skills, and understanding of the problem. If not, their involvement can be in the form of brainstorming and brainstorming (Syahrul, 2017: 4-5). Strategic planning decisions affect the physical, financial and organizational framework in which operations have been carried out. A typical organizational structure is characterized by three levels of management.

Componen of Strategic Plan.

The main component of strategic planning activities, according to McNamara (in Amirin, 2005: 25-29) consists of: (1) strategic analysis (strategic analysis), (2) strategic direction setting, and (3) ) action pianning.

1) Carry out strategic analysisStrategic analysis is an activity such as "scrutiny" of the state of the organization's environment. The environment includes the external environment and the internal environment. One of the most popular tools for conducting strategic analysis is the SWOT analysis. SWOT is an acronym for strength (weakness / weakness) (weaknesses / weaknesses), opportunities (opportunities / opportunities), and threats (threats). Strengths / weaknesses and weaknesses / shortcomings are internal organizational conditions, while opportunities / opportunities and threats / challenges are external conditions of the organization. 
2) Determination of the direction of strategic goals.

The other main component of strategic planning activities is the determination of the direction of strategic goals, namely "what must be done related to various issues (issues) important and opportunities faced" which include various "works" (or strategic goals) that must be achieved, as well as various methods (or strategies) to achieve the "work" (McNamara, in Amirin 2005: 27).A good objective formula contains the character "SMARTER", which is formulated: (1) specifically (2) measurable (measurable or easily "graded"), (3) acceptable ("accepted" agreed, agreed, not rejected by those who will make an effort to achieve the intended purpose), (4) realistic (according to reality), (5) timely (clearly defined period), (6) extending (according to the ability of those who will make an effort to achieve goals), and (7) rewarding (providing satisfaction-convenience to all parties).Lerner (in Amirin, 2005: 27) states that the criteria for formulating strategic goals are only five that are synchronized with SMART, but with slightly different terms. The five consists of: (1) specific, (2) measurable, (3) agreed upon formulation (McNamara uses acceptable terms), (4) realistic, and (5) time / cost bound (determined by the time and McNamara's budget to use timely terms). The way people formulate the mission statement (general purpose) is diverse, there are short concise ones, some are lengthy and detailed contain specific objectives that are part of the overall mission formulation (McNamara in Amirin, 2005: 28).

3) Action planningAction planning (activities) carefully describes how strategic goals will be achieved. In other words, in the long stretch of efforts to achieve these strategic objectives are a series of specific target chains. So, what is called a target is actually a goal too, only in smaller, narrower, or limited sizes (McNamara in Amirin, 2005: 30). According to McNamara (in Amirin, 2005: 30) each target is often associated with tactics to achieve it. Tactics is one of the methods needed to achieve goals. In other words, tactics are a strategy too, only in smaller sizes. Action planning (activities) also includes setting responsibilities and deadlines for each target. Obviously who determines who is needed to do certain activities and when to do them. In the planning of the action it was also stated a method for monitoring (monitoring) and evaluating the implementation of the plan which confirmed how the organization could find out who had carried out certain activities and when the activities were carried out (McNamara in Amirin, 2005: 30). Furthermore, according to McNamara (in Amirin, 2005: 30), in the planning of common actions an annual plan is also planned to be carried out in the coming year (the following year). This annual plan is sometimes referred to as an operational plan or management plan. It contains strategic objectives, strategies, goals, responsibilities and deadlines. Often an organization develops a plan (program) for each part (unit, department, section) in it which is commonly referred to as a work plan (work plans). In addition, the usual budget (budget) is included in the strategic plan, annual plan, or work plan. The budget determines the amount of money earmarked for the resources needed to implement the annual plan. The budget also determines how money will be used, for example for personnel, equipment, materials and so on (McNamara in Amirin, 2005: 31).

\section{Research Method}

Based on the characteristics of the problem, this study uses descriptive research with a qualitative approach. Creswell (in Noor 2011: 34), states that qualitative research methods are a complex picture, researching words, detailed reports from the views of respondents, and conducting studies on natural situations. Qualitative methods are descriptive research and tend to use analysis with an inductive approach. Descriptive research is research that seeks to describe a phenomenon, event, event that occurs now. Descriptive research focuses on actual problems as they were at the time of the research (Noor, 2011:34-35). The type of qualitative descriptive research used in this study is intended to obtain information about the strategic planning process at the Santa Rosa De Lima Tondano Catholic High School in Minahasa Regency in depth and comprehensively. In addition, a qualitative approach is expected to reveal the situation and problems faced and the efforts needed to overcome the problems in this activity. The study was conducted at the Santa Rosa De Lima Tondano Catholic High School in Minahasa District, when the research was conducted for 4 months, after the permission of the study.

The data used in this study are qualitative data obtained from interviews, observation and documentation studies. The data source of this study consisted of primary sources and secondary sources. Primary sources are Principal, Teachers, Students, Administrative Staff, Parents, School Partners, and Committees. While secondary sources are obtained from agency documents. The data collected by researchers generally involves a strategic planning process at the Santa Rosa De Lima Tondano Catholic High School in Minahasa Regency.The presence of researchers in the field in qualitative research according to Miles and Huberman (in Wahyuni, 2015: 74) is absolute, because researchers act as research instruments as well as data collectors. The benefits obtained from the presence of researchers as instruments are subjects more responsive to the presence of researchers, researchers can adjust to the research settings, decisions related to research can be taken in a fast and directed way, as well as information can be obtained through attitudes and ways of giving informants information. According to Sugiyono (in Wahyuni, 2015: 75), qualitative researchers as human instruments function to determine the focus of research, choose data source informants, collect data, assess data quality, analyze data, interpret data, and make conclusions on their findings. 
This research was conducted from December 2018 to February 2019 which began with the submission of research permits. Research permit issued by the Director of the Postgraduate Program, Manado State University. Through the permit, the researcher began the research by conducting interviews with the Principal, Former Principal, Deputy Principal, Teachers, School Development Team, school committee and several students in the period December 2018 to February 2019. Observation of facilities and infrastructure, schooling activities and the discovery of other secondary data were also carried out during this period. In this study the key instrument is the researcher himself. There for researchers are key instruments in observing, asking, understanding, and analyzing everything that happens at the research location. In this study researchers also used supporting instruments namely tape recorders and photo cameras. As stated by Moleong (2000: 35) that "every qualitative researcher needs to build a relationship with the subject of research which is a report card that is the relationship between the researcher and the subject that has fused so as if there is no separation wall between the two". So the researchers followed the steps as formulated by Nasution (1996), namely:

1. Orientation PhaseAt this stage, the activities carried out by the researcher are 1) observing the state of Santa Rosa De Lima Tondano Catholic High School 2) identifying and determining the focus of the problem then consulting with the supervisor related to the problem to be appointed as research object 3) looking for relevant literature according with the problems studied, through journals / articles, books, and the internet.

2. Exploration PhaseThis stage will be carried out if the submission of a research thesis proposal is accepted. The activities that will be carried out at this stage are conducting observations, interviews, studying documentation, making and analyzing field notes. So, after the Research Permit was issued, researchers immediately went down the field to research at the Santa Rosa De Lima Tondano Catholic High School by bringing all the necessary documents and tools.

3. Stage Member Check. The activities carried out at this stage are refining the results of the analysis carried out from the beginning in the form of a temporary report, asking the informant to provide feedback, record and analyze new information provided by the informant, and make corrections with the existing corrections. At this stage all the data obtained in the field, analyzed in such a way and then consulted with the supervisor and improve the things that will be corrected later.

The data in this study are qualitative data (data in the form of words), where the research variable is the Strategic Planning Process. The processing of data in this study is the processing of information obtained from the School that is the sample. After the data / information is obtained, then the analysis is carried out by following the steps as stated by Moleong (2000) as follows:1. Data reduction is done by making abstractions, namely making a summary summary of the results of the research.2. Compilation of data in units, to make it easier to describe each problem.3. Grouping each problem.4. Examination of the validity of data, which is associated with the theories used.5. Interpretation and conclusion as a result of research.

\section{Result And Discussion}

\subsection{The strategic planning process at Santa Rosa De Lima Tondano Catholic High School.}

The strategic planning process is seen as very important because of this process a document will be produced which becomes a reference for the implementation of the school program known as the school's strategic plan. This is supported by Handoko's statement (in Farhurohman, 2017: 74) which assesses that strategic planning is very important in building a work system that leads to achieving organizational goals. There are three things that underlie the importance of strategic planning, including: 1) Strategic planning providing a basic framework in all other forms of planning must be taken; 2) Understanding of strategic planning will make it easier to understand other forms of planning; 3) Strategic planning is the starting point for understanding and evaluating the activities of managers and organizations. Rowley et al (in Farhurohman, 2017: 75) explain that strategic planning is a formal process designed to help an organization maintain an optimal position with various important elements of the environment. Further more Steiner (in Farhurohman, 2017: 75) explains that through a strategic planning process an organization is equipped with a means that prioritizes orientation to the future, uses a system of approaches, allows for setting goals and strategies, provides a general framework for decisions and depends on performance measurement.

For this reason, the school strategic plan must be well made, in accordance with the vision and mission, the external and internal conditions of the school. So that achievement is also right on target, because it is in accordance with the conditions needed by local schools. This is also in line with the opinion of Imron (in Panjaitan, 2014: 1-2) stating that the School Work Plan document is a Strategic Plan for Educational Units which is prepared as a reference for developing the program from the school. This RKS document is produced through a systematic and continuous process that takes into account the potential, opportunities and constraints that exist or on the basis of predictions of the possible development of science, technology and art as a result of globalization.

Barnawi and Arifin (in Farhurohman, 2017: 76) explain school strategy planning is a process of looking at all aspects of the school and contains plans for how to advance the school. Strategic planning provides a "big 
picture" where schools are now going where and how to get to the destination. So strategic planning must be able to answer three main questions, namely where the current school position is, where the school will be taken and how to get the school to its destination. With good strategic planning, every school citizen can work towards the same vision based on the same mission and strive to achieve the same goal so that high commitment to the school organization is built. Thus a strategic plan is a result-oriented process that you want to achieve in a certain period of time by taking into account the potential, opportunities and constraints that may arise.

The strategic plan contains the determination of the vision and mission, setting goals, formulating targets and determining the strategy with the implementation of the strategic plan will be evaluated and the results as input for determining a better strategic plan.In this educational institution the school strategic plan has been compiled starting in 2015, whose idea originated from several members of the education observer community with the Principal who took office in 2015, where they wanted to make a guideline to direct the school program so that the school could grow better both in academic and non-academic terms. Then the Principal begins to discuss this with all stakeholders, and they agree to this good program. As a result, a school development team was formed which was one of the descriptions of its tasks to compile the school strategic plan. The formation of this team is a managerial decision from this educational institution. The team consists of 16 people, of which the majority of the education observer community is mostly from the education of S2 and generally lecturers, who are not staff / employees at the local school. This raises the view that staff / employees in this school are not directly involved in the strategic planning process.

This condition is contrary to the assertion of Barnawi and Arifin (in Farhurohman, 2017: 76) which explains that school strategic planning is carried out jointly by involving all stakeholders who have direct interests with schools such as school managers, parents of students, staff and school employees, school committees and education observer communities. So the team members should also be involved with parents, school employees and committees, because the school development team has a strategic function in school development. In general, the strategic planning process contains elements (1) formulation of vision and mission, (2) external environment assessment, (3) internal environment assessment, (4) formulation of strategic issues and (5) preparation of development strategies that can be added goals and objectives. And all of these stages have been carried out by this team, although there are differences in variations that can be seen in the existing strategic plan.

The strategic planning process does not have standard standards, but variations of each institution / organization by choosing and studying the existing procedures from various references. This is in accordance with what was explained by Djunaedi (in Farhurohman, 2017: 74) as follows: strategic planning does not recognize standard standards and the process has limited variation and each application needs to design its own variations according to local needs, situations and conditions. In the existing strategic plan, it is not divided into short, medium, and long-term plans, but each program is made more specific in the plans in the first, second, third and fourth years. Time-based planning is explained by Barnawi and Arifin (in Farhurohman, 2017: 75), namely long-term plans are defined as plans within three or four years. While the short-term plan is a plan that has a period of one year.

\subsection{The inhibiting factor in the strategic planning process is the Santa Rosa De Lima Tondano Catholic High School.}

In general, it can be said that the strategic planning process in this educational institution has been classified as good, although there are still some inhibiting factors in the process. And of all these inhibiting factors, everything can be minimized later when there are improvements to the school's strategic plan.These inhibiting factors are found by researchers that have an impact on current school conditions and situations: 1) The membership of the team tasked with the process of preparing the school Renstra does not involve people who are directly involved in or working in a local school because the school considers them unskilled in this case, and consequently there are several programs in the Strategic Plan, cannot be reached by schools because they are not made in accordance with existing conditions, 2) Strategic Plan formed is not socialized to stakeholders and the result of this lack of socialization makes all stakeholders less understanding the school strategic plan. 3) The time needed to prepare the Strategic Plan is quite long because many are seized by the busyness of each member and the distance of the domicile of each team member who is far apart, and 4) There is no budget available for this activity.

Factors that hinder and support are the drafting team. Because they are the ones who play an important role in the strategic planning process. Because there has been a change of headmaster, maybe this team will later be inactive again. So this opportunity is necessary for all stakeholders to train themselves to be skilled in making school development plans, which of course starts with analyzing the existing school conditions. Talking about inhibiting factors means talking about things that don't support the strategic planning process. For that we need to learn from existing mistakes, learn from existing shortcomings, and learn from existing mistakes so that later in the strategic planning process no inhibiting factors can be found as described earlier. To minimize the existing inhibiting factors, cooperation from all stakeholders is needed so that in the future this school will not only 
develop but become more advanced.

4.3. Supporting factors in the strategic planning process at Santa Rosa De Lima Tondano Catholic High School. In addition to the existing inhibiting factors, researchers also found supporting factors that support the strategic planning process in this school. Supporting factors include: 1) Members of the strategic planning team are truly skilled and skilled in their fields, this is the most important supporting factor because it is the expertise of team members who can perfect the team's work 2) There are some things that are still temporarily included in the Strategic Plan but already carried out / held (example: indihome), meaning the accuracy of the program to be held with local school needs is very targeted 3) Totality of self-giving from all team members, because even though they are not paid more for this job but they continue to work sincerely 4) There are donors who cover the cost, the intended fees are like consumption money when carrying out team work and rent a place for meeting / meeting time at Lotta.These factors provide opportunities for better improvement. Of course good cooperation from all school members is needed to maintain and even enhance the existing supporting factors. All school members must also support every school policy, so that the quality of this school's education will be more advanced.

4.4. Efforts can be made to overcome obstacles in the strategic planning process at the Santa Rosa De Lima Tondano: Catholic High SchoolThe strategic planning process in this educational institution still has shortcomings. However, the school did not stand idly by but did efforts to improve deficiencies in the strategic planning process. The school began to socialize the school strategic plan by distributing copies of documents to stakeholders, and from this document the school community especially the teachers had begun to understand and master the school strategic plan. By revisiting this document, they were curious and interested in finding out how to compile the strategic plan. From this, they naturally began to train themselves to analyze school conditions. And this will be followed by training by experts, who are currently championed by the current headmaster. Because learning with more experts will increase their insight, given the condition / busyness / age of the staff / employees who need a tutor to teach this. Then other efforts such as involving stakeholders and time and budget planning in the strategic planning process, have become efforts even though they are only verbal, but will be tried later when there are improvements to the school strategic plan later. Because considering that there is also only one year left when the school strategic plan takes effect, preparations for these school programs have begun.

\section{Conclussion}

Based on the results of research and discussion, the researchers concluded several things, namely as follows.

1. The strategic planning process at the Santa Rosa de Lima Tondano Catholic High School still has a variety of obstacles that have not fully implemented the programs in the strategic plan. The stages in this process are internal 5.headmaster talks with all stakeholders on the importance of preparing a school strategic plan, the formation of a strategic planning drafting team whose membership does not fully involve the residents of the school, division of tasks for team members, external and internal environmental analysis (SWOT), program preparation -school programs, Preparation of school strategic plans. The components of the school strategic plan are Introduction, History and Values, Vision and Mission, Profile of Graduates, Self Evaluation, School Strategic Objectives and Programs, and Performance Indicators. In general, there are thirteen points of school strategic programs, and their implementation until this year as the last year is in line with the period of strategic plan use since the new strategic plan was only around $50 \%$.

2. Factors that hinder the strategic planning process at Santa Rosa de Lima Tondano Catholic High School are: a) The membership of the team tasked with the process of preparing the school strategic plan does not directly involve people working or working in the local school, b) the Strategic Plan formed less socialized to stakeholders, c) The time needed to prepare the Strategic Plan is quite long because a lot is taken up by the busyness of each team member and d) There is no budget available for this activity.

3. Factors that support the strategic planning process at Santa Rosa de Lima Tondano Catholic High School are: 1) Expertise and skills of the members of the strategic planning team, 2) The accuracy of the program to be implemented with the local school needs on target 3) Totality of self-giving from all team members, 4) There are donors who cover costs.

4. Efforts made to overcome the factors that hamper the strategic planning process at Santa Rosa de Lima Tondano Catholic High School are involving people who work in these educational institutions because those who know more about general and special matters about schools, the time spent in preparing the Strategic Plan must be clearly arranged and team members should not be people who have high activity, socializing the strategic plan is not enough in just a few hours when the parents meeting and teachers should socialize it repeatedly with a copy Strategic documents and then distributed to all school members, before drafting the strategic plan should also make a budget plan and put together a committee, teacher, parents. 


\section{References}

Amirin, T. M. 2005. Model-Model Perencanaan Strategik. Jurnal Manajemen Pendidikan, 01, 24-36

Djunaedi, A. 2002. Proses Perencanaan Strategis Kota/Daerah. Bahan Kuliah MK Proses Perencanaan. UGM, Yogyakarta

Engkoswara, H; Komariah, A. 2010. Administrasi Pendidikan. Bandung: Alfabeta

Farhurohman, O. 2017. Faktor Kunci Keberhasilan Komponen Penyusunan Manajemen Perencanaan Strategis Sekolah. TARBAWI, 3 (1), 77-89.

Kewo, C. L. Pengaruh Penganggaran Partisipatif, Komitmen Organisasi Dan Pengendalian Intern Terhadap Kinerja Manajerial Aparatur Pemerintah Kabupaten Minahasa. Jurnal Riset Akuntansi dan Keuangan, 7(1), 29-42.

Kewo, C. L., \& Afiah, N. N. (2017). Does Quality of Financial Statement Affected by Internal Control System and Internal Audit?. International Journal of Economics and Financial Issues, 7(2), 568-573.

Kambey, E. S. 2016. Manajemen Mutu Terpadu dalam Pendidikan. Manado: Yayasan Tri Ganesha Nusantara

Lidinillah, D. A. M. 2013. Perencanaan Strategis Untuk Organisasi Kemahasiswaan. Materi Latihan Kepemimpinan, UPI, Tasikmalaya

Lubis, M. S. 2008. Perencanaan Strategik Pendidikan. Artikel STAI AL-HIKMAH MEDAN, 01, 45-59

Moleong, L. J. 2007. Metodologi Penelitian Kualitatif, Cet. XVI. Bandung: Remaja Rosdakarya

Mutmainnah. 2008. Perencanaan Strategik dan Implementasinya dalam Peningkatan Mutu Sekolah Target (Studi Kasus di SMPN 2 Plosoklaten Kabupaten Kediri). Tesis Program Pascasarjana Magister Manajemen Pendidikan Islam. Universitas Islam Negeri Maulana Malik Ibrahim, Malang

Nasution. 2011. Metode Penelitian Kualitatif Naturalistik. Jakarta: Sinar Grafika.

Noor, J. 2011. Metodologi Penelitian. Jakarta: Kencana

Panjaitan, T. B. 2014. Penyusunan Rencana Pengembangan Sekolah di SDN Kecamatan Padang Timur Kota Padang. Jurnal Bahana Manajemen Pendidikan, 1 (1), 2-13.

Peraturan Perundang-undangan:

Rencana Strategis Kemendikbud Tahun 2015-2019, Permendikbud RI No. 22 Tahun 2015 Pasal 1 ayat 2 Struktur penulisan dokumen rencana strategis, In Mendiknas No. 1/U/2002

Rojak, A.I. 2017. Implementasi Rencana Strategis dalam Meningkatkan Mutu Pendidikan Madrasah Swasta. Tesis Program Pascasarjana Magister Manajemen Pendidikan Islam. Universitas Islam Negeri Maulana Malik Ibrahim, Malang

Rusniati ; Ahsanul. 2014. Perencanaan Strategis Dalam Perspektif Organisasi. Jurnal INTEKNA, (2), 102-209

Saraswati. 2005. Kearifan Budaya Lokal Dalam Perspektif Teori Perencanaan. Junal PWK Unisba, 1-26.

Standar Pengelolaan Pendidikan oleh Satuan Pendidikan Dasar dan Menengah, Permendiknas RI No. 19 Tahun 2007 Pasal 1 ayat $1 \& 2$.

Sutisna, O. 1989. Administrasi Pendidikan (Dasar Teoritis Untuk Praktek Profesional). Bandung: Angkasa

Syahrul. 2017. Perencanaan Strategis dan Praktiknya di Perguruan Tinggi. Artikel IAIN Kendari, 1-18

Umam, K. 2007. Perencanaan Strategis Dalam Upaya Peningkatan Mutu Lulusan Di Madrasah Aliyah Negeri 1 Malang. Tesis Program Pascasarjana Magister Manajemen Pendidikan Islam. Universitas Islam Negeri Maulana Malik Ibrahim, Malang

Wahyuni, L.T. 2015. Perencanaan Strategik Madrasah Dalam Meningkatkan Mutu Pendidikan (studi multisitus di MTs Negeri Jabung Blitar dan MTs Negeri Gandusari Blitar). Tesis Program Pascasarjana Magister Manajemen Pendidikan Islam. Universitas Islam Negeri Maulana Malik Ibrahim, Malang

Widjaya, A.W. 1995. Perencanaan Sebagai Fungsi Manajemen. Jakarta: Rineka Cipta

Winardi, J. 2007. Motivation and Motivation in Management. Jakarta

Yunianto, M. 2010. Proses Perencanaan Strategis. Online. https://martinyunianto.wordpress.com/prosesperencanaan-strategis/2010. Diakses pada 5 Maret 2019 